\title{
Three new threatened Keetia species (Rubiaceae- Vanguerieae), from the forests of the Eastern Arc Mountains, Tanzania
}

\author{
M. Cheek \& D. Bridson \\ Royal Botanic Gardens, Kew, \\ Richmond, Surrey TW9 3AE \\ M.Cheek@kew.org
}

\begin{abstract}
Keetia sp. A, of the Flora of Tropical East Africa, based on Mabberley \& Salehe 1496, is formally named as Keetia davidii following the discovery of a second specimen, also from the Ukaguru Mountains of the Eastern Arc of Tanzania. This small tree or shrub is assessed as Endangered using the IUCN 2012 standard. Keetia sp. B, a shrub from Kwiro Forest near Mahenge, is described as Keetia mwasumbii. Based on Cribb et al. 11027, it is assessed as Critically Endangered. Keetia sp. C, formally named as Keetia semsei based on Semsei 2025, from the Shikurufumi Forest near the Uluguru Mountains, is also assessed as Critically Endangered. The three species each derive from separate threatened patches of forest that are among the least well-surveyed and least protected in the Eastern Arc Mountain archipelago. For this reason, naming them, so enabling inclusion in the IUCN Red List, is important if they are to be included in conservation prioritisation exercises.
\end{abstract}

Keywords. Conservation, Eastern Arc Mountains and Coastal Forests, Kwiro Forest, Shikurufumi Forest, Ukaguru Mountains

\section{Introduction}

Keetia E..Phillips (Rubiaceae: Vanguerieae) was resurrected, segregated from Canthium, by Bridson $(1985,1986)$. Restricted to Africa, this genus of about 35 species are mainly forest climbers, with some small trees. They are distinguished from Canthium and other allied genera in the tribe Vanguerieae in Africa by their pyrenes with a fully or partly defined lid-like area around a central crest (Bridson, 1986). In a phylogenetic analysis of the tribe based on morphology, nuclear ribosomal ITS and chloroplast trnT-F sequences, Lantz \& Bremer (2004), found that Keetia was monophyletic with strong support. Bridson's (1986) account of Keetia was preparatory to treatments of the Vanguerieae for the Flora of Tropical East Africa (Bridson, 1993) and Flora Zambesiaca (Bridson, 1998).

According to Bridson (1986), 'A large number of new species remain to be described' in Keetia. Several of these new species were indicated by her in that publication, and other new species by her arrangement of specimens in folders that she annotated in the Kew Herbarium (K). Some of these species were later taken up and published from West and Central Africa by other authors, such as Keetia bridsoniae Jongkind (2002). In the same paper Jongkind published Keetia obovata Jongkind, 
based on material not seen by Bridson. Also based previously on unpublished taxa informally indicated by Bridson, or on new material, additional new species of Keetia have been published from outside the Flora Zambesiaca and Flora of Tropical East Africa areas by Bridson \& Robbrecht (1993), Cheek (2006), Lachenaud et al. (2017) and Cheek et al. (2018). A further new species was published from Kenya (Bridson, 1994). Many more are likely to await description from unidentified material. For example, while 10 species are accepted in the Gabon checklist, based on a total of 20 identified specimens, a further 47 specimens remain unidentified to species (Sosef et al., 2005).

Three taxa of East African Keetia, indicated by Bridson as sp. A, B and C, remained formally unpublished (Bridson, 1993). This was because material was considered incomplete, each taxon being known from a single specimen. At that time the convention in this circumstance was to refrain from publishing new names. However, all three species were so distinct that they were included in the identification key to the 15 species of Keetia that were recognised from Uganda, Kenya and Tanzania (Bridson, 1993). In this paper we formally publish these species so that they can then be placed on the IUCN Red List (https://www.iucnredlist.org/) and included in conservation prioritisation exercises.

The number of flowering plant species described as new to science each year regularly exceeds 2000, adding to the estimated 369,000 already known (Nic Lughadha et al., 2016), although the number of flowering plant species known to science is disputed (Nic Lughadha et al., 2017). Only about 7\% of plant species have been assessed and included on the Red List using the IUCN (2012) standard (Bachman et al., 2019), but this number rises to $21-26 \%$ when additional evidence-based assessments are considered, and $30-44 \%$ of these assess the species as threatened (Bachman et al., 2018). Newly discovered species such as those reported in this paper are likely to be threatened, since widespread species tend to have been already discovered. There are notable exceptions to this rule, e.g., Cola pseudoclavata Cheek (Cheek \& Dorr, 2007) a species relatively widespread in coastal Tanzania and Kenya and assessed as Near Threatened (Cheek \& Lawrence, 2019). Generally, however, it is the more localised, rarer species that remain undiscovered, making them especially at risk from habitat clearance and/or other threat factors. This makes it all the more urgent to discover, document and protect such species before they become extinct, as may be Kihansia lovettii Cheek and Afrothismia baerae Cheek (Cheek, 2004a, 2004b) also of the Eastern Arc Mountains and Coastal Forests, neither of which have been seen at their single locations since they were published, despite subsequent targeted searches.

\section{Methodology}

Names of species and authors follow IPNI (2012). Herbarium material was examined with a Leica Wild M8 dissecting binocular microscope fitted with an eyepiece graticule measuring in units of $0.025 \mathrm{~mm}$ at maximum magnification. The drawing was made with the same equipment with a Leica 308700 camera lucida attachment. Pyrenes 
were characterised for each species, where available, by boiling selected ripe fruits for several minutes in water until the flesh softened and could be removed. Finally, a toothbrush was used to clean the exposed pyrene surface. Specimens were inspected from the following herbaria: $\mathrm{BM}, \mathrm{FHO}, \mathrm{K}, \mathrm{MO}$ and $\mathrm{P}$. The format of the description follows those in other papers describing new species of Keetia, e.g. Cheek et al. (2018). Technical terms follow Beentje \& Cheek (2003). Herbarium codes follow Index Herbariorum (Thiers, continuously updated).

The conservation assessments follow the IUCN (2012) standard. Grid references for the specimens were obtained by reference to Polhill (1988) and then entered into Google Earth to determine if habitat survived and whether threats were visible. Location names, derived from the specimens, were entered into Google to scan for information on conservation initiatives or threats.

\section{The new species}

\section{Keetia davidii Bridson \& Cheek sp. nov.}

Keetia davidii is similar to K. gueinzii (Sond.) Bridson (1986), differing in the much smaller leaves $2.2-5.1 \mathrm{~cm}$ long, $1.2-2.5 \mathrm{~cm}$ wide which are thinly leathery and glossy on the upper surface, and in which the tertiary nerves are inconspicuous. In Keetia gueinzii the leaves are 5.5-13.5 cm long, 3.5-6 cm wide, papery, matt and with the tertiary and quaternary nerves forming a conspicuous reticulum on the lower surface. - TYPE. Tanzania, Kilosa District, Ukaguru Mountains, Mamiwa Forest Reserve, summit of Mamiwa, 2300 m, fr. 16 August 1972, D.J. Mabberley \& S.S. Salehe 1496 (holotype K [K000592974]; isotypes DSM, EA) (Fig. 1)

Keetia sp. A Bridson, Kew Bull. 41: 972 (1986) 2; Bridson, Fl. Trop. E. Afr., Rub. (part 3): 913 (1993).

Small tree or shrub, occasionally lianescent, 2.5-3 m high. Leafy stems much branched, branches terete, $2-2.5 \mathrm{~mm}$ diam. below the leaves, pale grey brown, with numerous lenticels, third internode below stem apex 1.2-1.9 cm long, young branches golden appressed pubescent, hairs $0.5-0.75 \mathrm{~mm}$ long, $90-100 \%$ cover. Leaf blades thinly coriaceous, drying glossy black-brown above, surface finely wrinkled, dark brown below, narrowly ovate, $2.2-5.1 \mathrm{~cm}$ long, $1.2-2.5 \mathrm{~cm}$ broad, acumen $3-5 \mathrm{~mm}$ long, broad, rounded, base truncate to broadly rounded, lateral nerves $5-6(-7)$ on each side of the midrib, inconspicuous on upper surface, domatia in axils of secondary nerves with midrib, elliptic, $0.25-0.3 \mathrm{~mm}$ long, inner surface with a few golden straight hairs, tertiary and quaternary nerves inconspicuous; hairs appressed to midrib, golden yellow, $0.5-0.6 \mathrm{~mm}$ long, c. $30 \%$ cover, secondary nerves with similar but sparser indumentum, c. $10 \%$ cover. Petiole drying black, plano-convex, 2-4 mm long, indumentum as stem, but absent from adaxial face. Stipule narrowly triangular (at third node below apical bud), 5-6.5 mm long, tapering to an acutely filamentous apex, sheath c. $2 \mathrm{~mm}$ long, $2 \mathrm{~mm}$ broad, indumentum in a longitudinal band along the midline, tapering in width 
along the midline, hairs as stem, remainder of stipule surface glabrous. Inflorescences/ infructescences axillary, in opposite pairs in two successive nodes, placed 3-5 internodes below the apex, the entire inflorescence axis surface c. $50 \%$ covered in appressed golden hairs $0.35 \mathrm{~mm}$ long; peduncle 6-14 $\mathrm{mm}$ long, patent, lacking bracts, apex bifurcate, rhachises $3.5-5 \mathrm{~mm}$ long, sparingly branched, bracts oblong-ovate, $1.5-2.5 \times 0.75 \mathrm{~mm}$, apex acute. Flowers post-anthesis with pedicels 4-5 $\mathrm{mm}$ long; ovary hypanthium cylindric, c. $1.5 \mathrm{~mm}$ long, indumentum as pedicel; calyx tube shortly cylindric, $0.4-0.5 \mathrm{~mm}$ long, c. $1.3 \mathrm{~mm}$ wide; calyx lobes needle-like, c. $0.25 \mathrm{~mm}$ long, indumentum thinly scattered. Fruit drying black, broadly oblong in outline, $8-9 \mathrm{~mm}$ long, 10-12 $\mathrm{mm}$ wide, c. $8 \mathrm{~mm}$ broad, apex truncate, the disc indented, elliptic, c. 3 $\mathrm{mm}$ long, $2 \mathrm{~mm}$ wide, with inconspicuous calyx lobe remains; widest in the distal half, proximal half tapering to a rounded base; pyrene surface smooth, ellipsoid, c. $1 \mathrm{~cm}$ long, 6-7 mm wide, the ventral surface flattened with a shallow central longitudinal groove, c. $6 \mathrm{~mm}$ broad; the lid area subcircular, perpendicular to the ventral face, c. $3 \mathrm{~mm}$ wide, $4 \mathrm{~mm}$ broad, with a central thickened crest; pedicel not accrescent, thickened.

Distribution. Tanzania, Eastern Arc Mountains, known only from two collections in the Ukaguru Mountains of Kilosa District.

Habitat. Mist (cloud) forest 2000-2300 malt., with Syzygium spp., Polyscias stuhlmannii Harms, Celastraceae, Aphloia theiformis (Vahl) Benn., Ocotea usambarensis Engl. and Psychotria mahonii C.H.Wright.

Etymology. Named for David Mabberley (1948-) who co-collected the type and first known specimen of this species (for which there are only two records) during fieldwork for his doctoral research. His specimens made with Salehe from the Ukaguru Range are among the most important from that under-collected area of the Eastern Arc Mountains, and from them he is also commemorated by Senecio mabberleyi C.Jeffrey (Polhill \& Polhill, 2015).

Additional specimen examined. TANZANIA: Morogoro: Kilosa District, Mikumi division, Ilole Forest, montane evergreen forest, SE facing slope with fr., 9 Feb. 2007, Mwangoka \& Kidanka 5129 (DSM (n.v.), K, MO (n.v.)).

Provisional IUCN conservation assessment. The two sites known for this species are separated by about $114 \mathrm{~km}$. The type location is Mamiwa forest reserve in the Ukuguru Mountains for which the georeference given in Polhill (1988) is $6^{\circ} 25^{\prime} \mathrm{S}, 36^{\circ}$ $59^{\prime} \mathrm{E}$ (and for which Mabberley is given as the sole collector). The second location, given as Ilole Forest $\left(7^{\circ} 26^{\prime} \mathrm{S}, 36^{\circ} 44^{\prime} \mathrm{E}\right)$ appears to be unprotected. Both sites have intact original forest at their centre, but appear to be threatened by fires encroaching on their outer edges (viewed on Google Earth, 25 May 2019, Digital Globe imagery dated Oct. 2013 to Aug 2018). The altitude range indicated (2000-2300 m) suggests that the potential area suitable for this species is not large, perhaps $<20 \mathrm{~km}^{2}$, since only a few of the mountain tops with surviving forest in this area attain this range. 


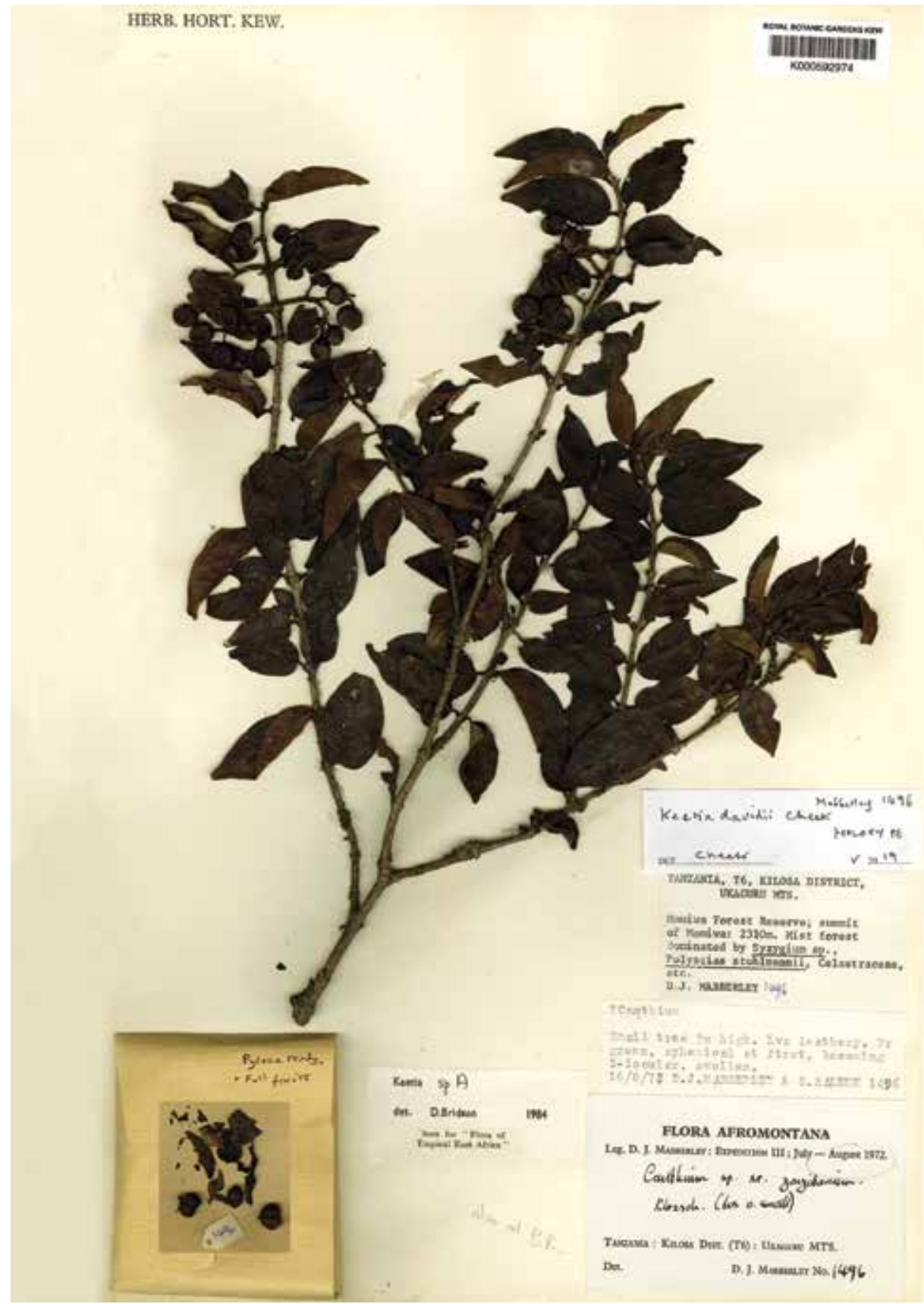

Fig. 1. Keetia davidii Bridson \& Cheek (Rubiaceae). From D.J. Mabberley \& S.S. Salehe 1496. (Photo: I.M. Turner).

This area is therefore taken as the area of occupancy in the sense of IUCN (2012). Therefore, the species is here assessed as Endangered EN B2ab(iii). It is to be hoped that conservation actions will be taken to protect Keetia davidii. Key to this would be 
further surveys to discover if additional sites exist beyond those two documented in this paper. The Tanzanian Forest Conservation Group (TFCG, http://www.tfcg.org/) work with communities impacting seven of the Eastern Arc forest blocks, supporting sustainable forest conservation options, but sadly not yet the Ukaguru Mountains. Invoking their assistance to protecting the Ukaguru Mountains, or using their model as a template for application in the Ukaguru Mountains, is advisable. Seedbanking of Keetia davidii should be explored although it is not known if this species has orthodox (seedbankable) seeds or not.

Notes. The Mabberley specimen was first recognised as a likely distinct species, Keetia sp. A, by Bridson (1986). This position was maintained in the Flora of Tropical East Africa account (Bridson, 1993) where it was stated that additional collections were needed to clarify the status of the specimen since it might possibly represent a reduced form of K. gueinzii. Additional material was finally obtained in 2007 (Mwangoka \& Kidanka 5129), from another site more than $100 \mathrm{~km}$ further south than the first. The two specimens match each other closely in the distinctive small leaves remarked upon by Bridson (1986, 1993), but also in several additional features e.g. in the leathery leaves, in which all but the secondary nerves are highly inconspicuous. Further features separating Keetia sp. A, here named as $K$. davidii, from $K$. gueinzii, are shown below in Table 1.

\section{Keetia mwasumbii Bridson \& Cheek, sp. nov.}

Keetia mwasumbii is similar to $K$. procteri Bridson, differing in the leaf-blades with 4-5 lateral nerves on each side of the midrib; fruit semi-circular in side view, flattened above, indented at apex, pyrene with lid-like area lying across apex. In Keetia procteri the leaf-blades have 5-9 lateral nerves on each side of the midrib, the fruit is ovoid and the pyrene has the lid-like area lying across the ventral face. - TYPE: Tanzania, Ulanga District, Kwriro Forest Reserve, SW flank of ridge, fr. 18 January 1979, P. Cribb, C. Grey-Wilson \& L. Mwasumbi 11027 (holotype K [K000592976]; isotypes DSM, EA) (Fig. 2).

Keetia sp. B Bridson, Kew Bull. 41: 976 (1986); Bridson, Fl. Trop. E. Afr., Rub. (part 3): 916 (1993).

Shrub 2 m tall. Young stems glabrous, laterally slightly flattened, drying black, finely longitudinally wrinkled, older stems dull white. Lateral branches developing on one side only and subtending leaves apparently absent. Leaf-blades drying black above, dark brown below, thinly coriaceous, broadly elliptic, $3-5.5 \mathrm{~cm}$ long, $1.5-3.2 \mathrm{~cm}$ broad, apex acute, subacuminate or obtuse, and then sometimes apiculate, base obtuse, lateral nerves 4-5 on each side of the midrib, domatial tufts $0.3 \mathrm{~mm}$ diam., of dense redbrown erect hairs, tertiary nerves inconspicuous, midrib with sparse, stout, stiff, orange appressed hairs $0.25 \mathrm{~mm}$ long. Petioles shallowly canaliculate, 4-6 mm long, with a few very sparse partly appressed hairs as on the leaf-blade. Stipules triangular at base, 
Table 1. Diagnostic characters separating Keetia davidii from K. gueinzii. Characters for K. gueinzii from Bridson (1993).

\begin{tabular}{lll}
\hline Character & K. gueinzii & K.davidii \\
\hline Leaf dimensions & $\begin{array}{l}5.5-13.5 \mathrm{~cm} \text { long, 3.5-6 cm } \\
\text { wide }\end{array}$ & $\begin{array}{l}2.2-5.1 \mathrm{~cm} \text { long, 1.2-2.5 cm } \\
\text { wide }\end{array}$ \\
$\begin{array}{l}\text { Leaf blade venation, } \\
\text { abaxial surface }\end{array}$ & $\begin{array}{l}\text { Tertiary and quaternary nerve } \\
\text { reticulation conspicuous }\end{array}$ & $\begin{array}{l}\text { Tertiary and quaternary nerve } \\
\text { reticulation not visible }\end{array}$ \\
Leaf texture & Chartaceous & Thinly coriaceous \\
Stem indumentum & Red, patent & Golden, adpressed \\
Stipules & Lanceolate to ovate, 9-13 mm & Narrowly triangular, 5-6.5 $\mathrm{mm}$ \\
& long & long \\
\hline
\end{tabular}

apex subulate, 2.25-3.5 mm long, indumentum as petioles, caducous. Inflorescences unknown. Infructescences 3-4-fruited, peduncle $0.5-1 \mathrm{~cm}$ long, glabrous, bifurcate into two rhachises at apex; bracts thinly scattered, mainly subtending branches, oblong, 2-3 mm long, c. $0.3 \mathrm{~mm}$ wide, apex long-acute, adaxial surface densely hairy, hairs as on petiole. Pedicels $0.6-1 \mathrm{~cm}$ long, sparsely pubescent. Fruit semi-circular in outline, more or less truncate above, $1 \mathrm{~cm}$ long, $1.4-1.5 \mathrm{~cm}$ wide, 5-6 mm broad, lightly depressed at apex; with a broad, shallow longitudinal groove between the two locules; disc flattened, $2 \mathrm{~mm}$ diam., calyx teeth $1 \mathrm{~mm}$ long, arching over disc; pyrene shortly obovoid, ventral face flattened, 9-12 $\mathrm{mm}$ long, 7-8 $\mathrm{mm}$ wide at apex, 5-6 $\mathrm{mm}$ broad, point of attachment at apex; lid area circular, perpendicular to ventral face, elevated away from the central axis, crest broad and low.

Distribution. Known only from Tanzania, Ulanga District, Kwiro Forest reserve near Mahenge.

Habitat. Cloud (submontane) forest, $1400 \mathrm{~m}$ alt.

Etymology. Named for Leonard Mwasumbi (1938-2013), co-collector of the type and only known specimen. He was the mainstay of DSM at the Botany Dept., University of Dar es Salaam from the 1960s rising to become principal scientist. He collected many thousands of herbarium specimens and was renowned for his outstanding knowledge of the Tanzanian Flora and its uses. He is commemorated in the names of several other species, and in the rare and threatened Annonaceae genus Mwasumbia Couvreur \& D.M.Johnson (Polhill \& Polhill, 2015: 331).

Provisional IUCN conservation assessment. Keetia mwasumbii is known from a single site, Kwiro Forest Reserve which is indicated at $8^{\circ} 41^{\prime} \mathrm{S}, 36^{\circ} 41^{\prime} \mathrm{E}$ in Polhill (1988). Viewing the Digital Globe satellite imagery dated 6 Oct. 2017 on Google Earth (viewed 29 May 2019) at this georeference shows a poorly delineated forest patch 
extending from 700-900 m alt., aligned N-S, at the bottom of a $\mathrm{W}$ facing N-S ridge. The patch measures c. $1.5 \mathrm{~km} \mathrm{~N}$ to $\mathrm{S}$ and is about $0.5 \mathrm{~km}$ at its widest extent, but mainly only $0.2 \mathrm{~km}$ wide. The western boundary is abutted by a network of fields, while the ragged eastern boundary appears to be threatened by encroachment, probably due to the proximity to the expanding town of Mahenge, which now extends to within $1 \mathrm{~km}$ of Kwiro Forest reserve. Notes in Cribb et al. 11027 state that their specimen was collected in 1979 just below the ridge on the SW flank, at $1400 \mathrm{~m}$ altitude. This is a concern, suggesting that the forest reserve was until recently much larger. Forest is now all but absent from the area described, probably cleared to supply the needs of Mahenge. However, a small patch was found on Google Earth (imagery described above) west of a ridge at $1300 \mathrm{~m}$ alt., at $8^{\circ} 42^{\prime} 30^{\prime \prime} \mathrm{S}, 36^{\circ} 42^{\prime} 15.4^{\prime \prime} \mathrm{E}$ and it is possible that the species might survive there. Using IUCN (2012) preferred $4 \mathrm{~km}^{2}$ grid cells, the area of occupancy can be calculated as $4 \mathrm{~km}^{2}$. Therefore, the species is here assessed as Critically Endangered CR B2ab(iii). It is to be hoped that conservation actions will be taken to protect Keetia mwasumbii including a public sensitisation programme in Mahenge on the importance of this minute forest and its unique species, if it still survives.

Notes. Bridson (1986: 976) notes that the species is unusual in combining the characters of leaves with obscure tertiary venation with pyrenes in which the lid like area lies across the apex.

Brachystephanus schliebenii (Mildbr.) Champl. is also a point endemic of Mahenge, and is also only known from the type collection, Schlieben 2000, made in March 1932 at about 1000-1200 m alt. (Champluvier \& Darbyshire, 2009: 147). It was provisionally assessed as Critically Endangered CR B1ab(iii) B2ab(iii) by Darbyshire in Champluvier \& Darbyshire (2009: 124). If it has survived extinction, it may well be in the same forest as Keetia mwasumbii, since there seems to be little other forest at Mahenge.

\section{Keetia semsei Bridson \& Cheek}

Keetia semsei is similar to K. lulandensis Bridson, K. zanzibarica (Klotzsch) Bridson and $K$. koritschoneri Bridson, differing in the stipules which are linear-lanceolate, 5-6 $\mathrm{mm}$ long; leaf-blades acute to subacuminate at apex; domatia present as inconspicuous tufts of rusty coloured hairs; pyrene not indented in ventral face. In Keetia lulandensis, $K$. zanzibarica and $K$. koritschoneri, the stipules are narrowly oblong, 2-4 $\mathrm{mm}$ long, apex more or less truncate, the leaf-blades acuminate, the domatial tufts are white and conspicuous; and the pyrene has an indentation below the point of attachment on the ventral face. - TYPE: Tanzania, Morogoro District, Shikurufumi Forest Reserve, March 1955, S.R. Semsei 2025 (holotype K [K000592975]; isotypes EA, TFD) (Fig. $3)$.

Keetia sp. C Bridson, Kew Bull. 41: 982 (1986); Bridson, Fl. Trop. E. Afr., Rub. (part 3): 921 (1993) 


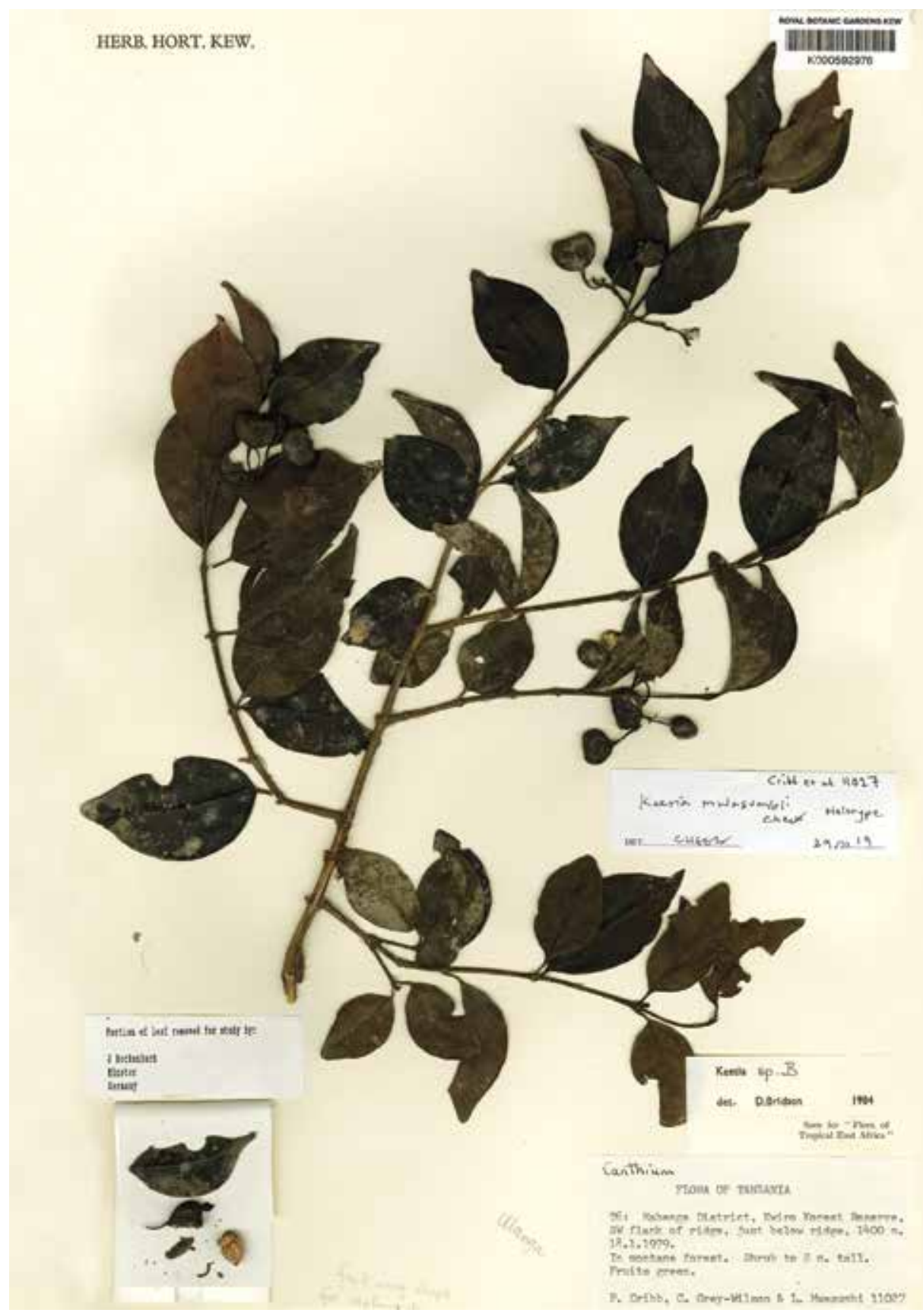

Fig. 2. Keetia mwasumbii Bridson \& Cheek (Rubiaceae). From P. Cribb et al. 11027. (Photo: I.M. Turner).

Climber. Young stems grey-green, slightly laterally flattened, glabrous. Leaf blades thinly coriaceous, drying black above, dark brown below, broadly elliptic, $4.5-9 \mathrm{~cm}$ long, $2.5-4.5 \mathrm{~cm}$ wide, apex acute to subacuminate, base obtuse to rounded, secondary 
nerves 5-6(-7) on each side of the midrib; domatia inconspicuous, c. $0.3 \mathrm{~mm}$ diam. with dense tufts of rust-coloured hairs; tertiary nerves inconspicuous, glabrous; leaves subtending axillary branches not observed. Petiole drying black, plano-convex in transverse section, $0.7-1.2 \mathrm{~cm}$ long, sparsely puberulent to glabrous with thinly scattered stout orange appressed hairs $0.3-0.6 \mathrm{~mm}$ long. Stipules linear-lanceolate, 5-6 mm long, sheath c. $1 \mathrm{~mm}$ long, indumentum of outer surface as petiole, caducous, falling to expose a ring of colleters around the node, colleters black, stout, erect, 0.5 $\mathrm{mm}$ long, c. $0.2 \mathrm{~mm}$ broad, conspicuous. Inflorescences not observed. Infructescences 3-5-fruited, with peduncles 1-1.3 cm long, glabrous; bracts caducous, not observed. Pedicels 6-8 mm long, sparsely pubescent, hairs as petiole. Fruit oblong cordate in profile, $1.6-1.8 \mathrm{~cm}$ long, $1.5-1.6 \mathrm{~cm}$ wide, $0.9-1 \mathrm{~cm}$ broad, apex retuse by $2 \mathrm{~mm}$, base rounded; calyx limb persistent, dentate, teeth $1 \mathrm{~mm}$ long, concealing disc; pyrene ellipsoid, ventral face flattened, $1.6 \mathrm{~cm}$ long, $0.9 \mathrm{~cm}$ wide, $1 \mathrm{~cm}$ wide, point of attachment not evident, lid-like area on ventral face, not clearly demarcated, central crest not conspicuous.

Distribution. Known only from Tanzania, Morogoro District, Shikurufumi Forest Reserve.

Habitat. Evergreen lowland forest 1100-1400 m alt. [500-800 m alt. is indicated in Bridson (1993) but see conservation assessment below].

Etymology. named for the late S.R. Semsei (with his name as a noun in apposition), collector of the type and only known specimen. He is the only collector listed in Polhill (1988) for the Shikurufumi Forest Reserve. He was a major collector, making thousands of plant specimens during his period of service with the Tanganyika Forestry Service, starting in 1948 and continuing to 1972. His main set of specimens is at TFD (Lushuto Herbarium) but with many duplicates at EA, K, BR and WAG. Six species are named for him, including Coffea semsei (Bridson) A.P.Davis and Garcinia semseii Verdc. (Polhill \& Polhill, 2015: 422-423; IPNI, 2012).

Provisional IUCN conservation assessment. Keetia semsei is known from a single site, Shikurufumi also known as Chigurufumi Forest Reserve (Semsei 2025). This site is given as $7^{\circ} 10^{\prime} \mathrm{S}, 37^{\circ} 31^{\prime} \mathrm{E}$ by Polhill (1988). Viewing the Landsat/Copernicus satellite imagery dated 3 Oct. 2017 on Google Earth (viewed 29 May 2019) shows a well-delineated dagger-shaped forest patch extending from 1170-1400 m alt., aligned NW-SE, S of Morogoro and about $10 \mathrm{~km} \mathrm{~W}$ of the well-known and relatively wellsurveyed Uluguru Reserve. The Shikurufumi forest patch is about $3.5 \mathrm{~km}$ long on its main axis, and about $0.9 \mathrm{~km}$ wide in the central part. The southern third has tree cover of $<50 \%$. In the North there is a cleared area within the boundary and indications of agricultural encroachment at the boundary. However, the centre of the reserve has an intact tree canopy. Additionally, the Eastern Arc Mountain Endowment Fund (2008) reports that this forest, of $260 \mathrm{Ha}$, is threatened by "firewood and poles extraction, fire and forest clearing". Using IUCN (2012) preferred $4 \mathrm{~km}^{2}$ grid cells, the area of 


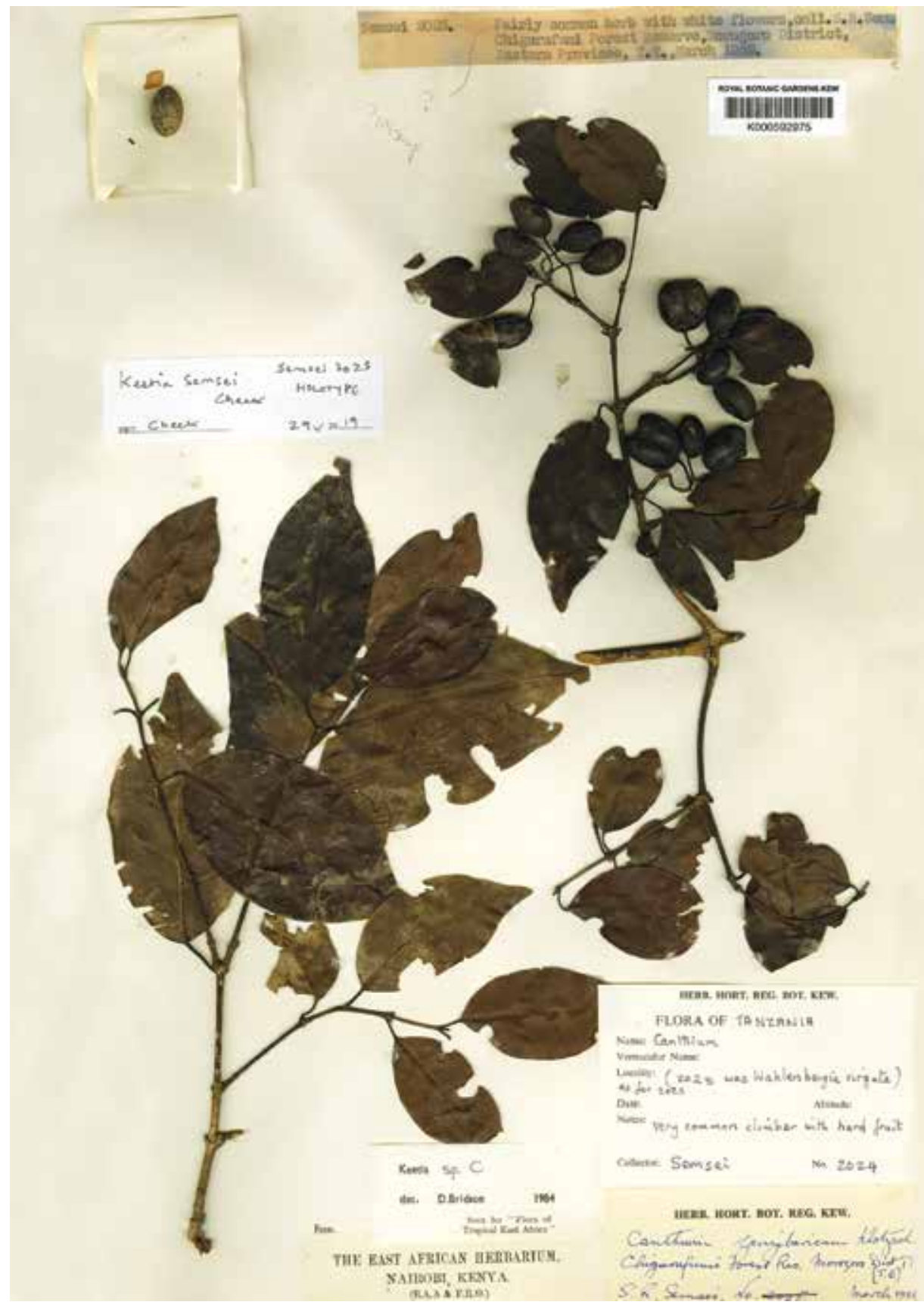

Fig. 3. Keetia semsei Bridson \& Cheek (Rubiaceae). From S.R. Semsei 2025. (Photo: I.M. Turner).

occupancy can be calculated as $4 \mathrm{~km}^{2}$. This is an over-estimate necessitated by the IUCN preference. Therefore, the species is here assessed as Critically Endangered $\mathrm{CR}$ B2ab(iii). It is to be hoped that conservation actions will be taken to protect 
Keetia semsei, such as a survey to discover the size and extent of the population at Shikurufumi, and the inclusion of this species in the management plan for the reserve.

Notes. The species is unusual for the fruits that are longer than wide, larger than those of most species, and with pyrenes with the lid-like area in the ventral position (Bridson, 1986: 982).

\section{A note on the Eastern Arc Mountains and Coastal Forests of East Africa}

The Eastern Arc mountains and Coastal Forests (EACF) of East Africa are found in Tanzania and southern Kenya. They form an archipelago-like phytogeographical unit well-known for high levels of species endemism in many groups of organisms (Gereau et al., 2016). Among the better known mountain blocks are the Nguru Mountains, the Udzungwa Mountains, the Uluguru Mountains, and the Usambara Mountains. The Ukaguru Mountains, home of Keetia davidii, the Kwiro Forest Reserve, home of $K$. mwasumbii, and Shikurufumi Forest Reserve, home of K. semsei, are among the least known, least well surveyed, and least protected forest patches. Supported by moist air currents from the Indian Ocean, the surviving evergreen forests of the Eastern Arc Mountains alone have 223 species of endemic tree (Lovett, 1998), and are variously stated to have 800 (Tanzanian Forest Conservation Group, undated) or as many as 1500 (Skarbek, 2008) endemic plant species. In herbaceous groups such as the Gesneriaceae, over $50 \%$ of the taxa (23 endemic species and a further nine endemic taxa) for East Africa (Uganda, Kenya and Tanzania) are endemic to the Eastern Arc Mountains (Darbyshire, 2006), and in the Acanthaceae there are numerous endemic species in multiple genera endemic to the Eastern Arc Mountains, e.g. Stenandrium warneckei, Isoglossa bondwaensis and Sclerochiton uluguruensis (Vollesen, 2008; Darbyshire, 2009; Darbyshire et al., 2010). In terms of documented plant species diversity per degree square, the Eastern Arc Mountains are second only in tropical Africa to Southwest Cameroon in the Cross-Sanaga Interval of West-Central Africa (Barthlott et al., 1996; Cheek et al., 2001). Several forest genera have disjunct distributions, being found only in the Cross-Sanaga Interval and in the EACF and not in between, e.g. Zenkerella Taub. and Kupea Cheek (Cheek et al., 2003, Cheek, 2004a). The EACF include the sole representatives of plant groups otherwise restricted on the continent to the forests of Guineo-Congolian Africa, e.g. Afrothismia Schltr. and Ancistrocladus Wall. (Cheek \& Jannerup, 2006; Cheek et al., 2000). Extensive forest clearance within the last 100-150 years has removed forest from some mountains entirely, and reduced forest extent greatly in others. Since the 1970s more than $12 \%$ of these forests have been cleared (Tanzania Forest Conservation Group, undated). Yet species such as these three Keetia species are still being published steadily. Let us hope that their homes can be preserved and their extinction avoided. 
ACKNOWLEDGEMENTS. The first author is grateful to Alistair Hay for his relentlessness and generosity in encouraging the writing of this paper, and to Kaj Vollesen for discussion on the Ukaguru Mountains. Ian Turner is thanked for producing the images.

\section{References}

Bachman, S.P., Nic Lughadha, E.M. \& Rivers, M.C. (2018). Quantifying progress towards a conservation assessment for all plants. Conservation Biol. 32: 516-524.

Bachman, S.P., Field, R., Reader, T., Raimondo, D., Donaldson, J., Schatz, G.E. \& Nic Lughadha, E.M. (2019). Progress, challenges and opportunities for Red Listing. Biol. Conservation 234: 45-55.

Barthlott, W., Lauer, W. \& Placke A. (1996). Global distribution of species diversity in vascular plants: towards a world map of phytodiversity. Erkunde 50: 317-328 [with supplement and figure].

Beentje, H. \& Cheek, M. (2003). Glossary. Flora of Tropical East Africa. Lisse: Balkema.

Bridson, D.M. (1985). The reinstatement of Psydrax (Rubiaceae, subfam. Cinchonoideae tribe Vanguerieae) and a revision of the African species. Kew Bull. 40: 687-725.

Bridson, D.M. (1986). The reinstatement of the African genus Keetia (Rubiaceae, Cinchonoideae, Vanguerieae). Kew Bull. 41 (4): 956-994.

Bridson, D.M. (1993). Keetia. In: Bridson, D.M. \& Verdcourt, B. Rubiaceae (Part 3). Flora of Tropical East Africa, pp. 909-923. Rotterdam/Brookfield: A.A. Balkema.

Bridson, D.M. (1994). A new species of Keetia (Rubiaceae-Vanguerieae) and notes on the Kayas of the Kenya Coast. Kew Bull. 49: 803-807.

Bridson, D.M. (1998). Rubiaceae (Tribe Vanguerieae). Flora Zambesiaca, vol. 5, pt. 2. UK: Royal Botanic Gardens, Kew.

Bridson, D.M. \& Robbrecht, E. (1993). A spiny-fruited new Keetia (Rubiaceae, Vanguerieae) from Kivu (Zaire). Belg. J. Bot. 126: 29-32.

Champluvier, D. \& Darbyshire, I. (2009). A revision of the genera Brachystephanus and Oreacanthus (Acanthaceae) in tropical Africa. Syst. \& Geogr. Pl. 79(2): 115-192.

Cheek, M. (2004a). Kupeaeae, a new tribe of Triuridaceae from Africa. Kew Bull. 58: 939-949.

Cheek, M. (2004b). A new species of Afrothismia (Burmanniaceae) from Kenya. Kew Bull. 58: 951-955.

Cheek, M. (2006). A new species of Keetia (Rubiaceae-Vanguerieae) from Western Cameroon. Kew Bull. 61(4): 591-594.

Cheek, M. \& Dorr, L. (2007). Sterculiaceae. Flora of Tropical East Africa. UK: Royal Botanic Gardens, Kew.

Cheek, M. \& Jannerup, P. (2006). A new species of Afrothismia (Burmanniaceae) from Tanzania. Kew Bull. 60: 593-596.

Cheek, M. \& Lawrence, P. (2019). Cola pseudoclavata. The IUCN Red List of Threatened Species 2019: e.T111397669A111449482. http://dx.doi.org/10.2305/IUCN.UK.20191.RLTS.T111397669A111449482.en. Accessed 27 May 2019.

Cheek, M., Frimodt-Moeller, C. \& Hoerlyck, V. (2000). A new submontane species of Ancistrocladus from Tanzania. Kew Bull. 55: 207-212.

Cheek, M., Mackinder, B., Gosline, G., Onana, J.-M. \& Achoundong, G. (2001). The phytogeography and flora of western Cameroon and the Cross River-Sanaga River interval. Syst. \& Geogr. Pl. 71: 1097-1100. 
Cheek, M., Williams, S. \& Etuge, M. (2003). Kupea martinetugei, a new genus and species of Triuridaceae from western Cameroon. Kew Bull. 58: 225-228.

Cheek, M., Magassouba, S., Molmou, D., Seny Doré, T., Couch, C., Yasuda, S., Gore, C., Guest, A., Grall, A., Larridon, I. et al. (2018). A key to the species of Keetia (RubiaceaeVanguerieae) in West Africa, with three new, threatened species from Guinea and Ivory Coast. Kew Bull. 73: 56.

Darbyshire, I. (2006). Gesneriaceae. Flora of Tropical East Africa. UK: Royal Botanic Gardens, Kew.

Darbyshire, I. (2009). Taxonomic notes and novelties in the genus Isoglossa (Acanthaceae) from east Africa. Kew Bull. 64(3): 401-427.

Darbyshire, I., Vollesen, K. \& Kelbessa, E. (2010). Acanthaceae (Part 2). Flora of Tropical East Africa. Royal Botanic Gardens, Kew.

Eastern Arc Mountain Endowment Fund (2008). Forest reserves, amphibians and birds of the Eastern Arc Mountains. www.easternarc.or.tz/groups/webcontent/documents/pdf/ Species\%20by\%20Forest\%20Reserves\%20Report.pdf. Accessed 29 May 2019.

Gereau, R.E., Cumberlidge, N., Hemp, C., Hochkirch, A., Jones, T., Kariuki, M., Lange, C.N., Loader, S.P., Malonza, P.K., Menegon, M. et al. (2016). Globally Threatened Biodiversity of the Eastern Arc Mountains and Coastal Forests of Kenya and Tanzania. J. E. Afr. Nat. Hist. 105(1): 115-201.

IPNI (2012). The International Plant Names Index. http://ipni.org/. Accessed May 2019.

IUCN (2012). IUCN Red List Categories and Criteria: Version 3.1., $2^{\text {nd }}$ edition. Gland, Switzerland and Cambridge, UK: IUCN.

Jongkind, C. H. (2002). Two new species of Keetia (Rubiaceae) from West Africa. Kew Bull. 57(4): 989-992.

Lachenaud, O., Luke, Q. \& Bytebier, B. (2017). Keetia namoyae (Rubiaceae, Vanguerieae), a new species from eastern Democratic Republic of Congo. Candollea 72: 23-26.

Lantz, H. \& Bremer, B. (2004). Phylogeny inferred from morphology and DNA data: characterizing well-supported groups in Vanguerieae (Rubiaceae). Bot. J. Linn. Soc. 146: 257-283.

Lovett, J.C. (1998). Importance of the Eastern Arc Mountains for vascular plants. J. E. Afr. Nat. Hist. 87: 59-74.

Nic Lughadha, E., Govaerts, R., Belyaeva, I., Black, N., Lindon, H., Allkin, R., Magill, R.E. \& Nicolson, N. (2016). Counting counts: revised estimates of numbers of accepted species of flowering plants, seed plants, vascular plants and land plants with a review of other recent estimates. Phytotaxa 272: 82-88. https://doi.org/10.11646/phytotaxa.272.1.5

Nic Lughadha, E., Bachman, S.P. \& Govaerts, R. (2017). Plant fates and states: response to Pimm \& Raven. Trends Ecol. Evol. 32: 887-889.

Polhill, D. (1988). Flora of Tropical East Africa: index of collecting localities. UK: Royal Botanic Gardens, Kew.

Polhill, D. \& Polhill, R. (2015). East African Plant Collectors. UK: Royal Botanic Gardens, Kew, Kew Publishing.

Skarbek, C. (2008). A review of endemic species in the Eastern Arc Afromontane Region: importance, inferences, and conservation. Macalester Rev. Biogeogr. vol. 1: article 3. http://digitalcommons.macalester.edu/biogeography/voll/iss 1/3

Sosef, M.S.M., Wieringa, J.J., Jongkind, C.C.H., Achoundong, G., Azizet Issembe, Y., Bedigian, D., van den Berg, R.G., Breteler, F.J., Cheek, M., Degreef, J. et al. (2005). Checklist of Gabonese vascular plants. Scripta Botanica Belgica 35. Meise: National Botanic Garden of Belgium. 
Tanzania Forest Conservation Group (undated). Eastern Arc Mountain Forests. http://www. tfcg.org/where-we-work/eastern-arc-mountains/. Accessed 26 May 2019.

Thiers, B.M. (continuously updated). Index Herbariorum: A global directory of public herbaria and associated staff. New York Botanical Garden. http://sweetgum.nybg.org/ ih/. Accessed Jan. 2017.

Vollesen, K. (2008). Acanthaceae (Part 1). Flora of Tropical East Africa. UK: Royal Botanic Gardens Kew. 
